\author{
Mateja Gabaj \\ Koprivnica \\ Jelena Kuvač Kraljević \\ Sveucílišste u Zagrebu, Edukacijsko-rehabilitacijski \\ fakultet, Odsjek ra logopediju
}

\section{Označavanje likova u dječjem pripovjednom diskursu}

\author{
Referring expressions in the children's \\ narrative discourse
}

\begin{abstract}
SAŽETAK
Pripovijedanje se u znanstvenoistraživačkom i stručnom logopedskom radu smatra dovoljno prirodnom i neposrednom alatkom jezične procjene, kojom se može vjerodostojno prikazati govornikova uporaba jezika na razini iznad rečenice. Prikladno označavanje i održavanje likova u priči, jedno je od načela kojim dijete treba ovladati kako bi se oblikovanim diskursom osigurala učinkovita komunikacija sa slušateljstvom. U skladu s tim, cilj je ovog rada ispitati označavanje likova u pričama potaknutim slikovnim materijalom iz hrvatske verzije Multilingual Assessment Instrument for Narratives (MAIN-a). U ispitivanju je sudjelovalo 23 djece predškolske i 23 djece rane školske dobi te 23 odraslih ispitanika, koji su trebali na osnovi slikovnih predložaka ispričati priču. Ispitivanje pokazuje da se djeca razlikuju od odraslih načinom ponovnog uvođenja likova s obzirom na sve tri promatrane vrste anafore - imensku, zamjeničku i nultu. U održavanju likova mlađa se djeca razlikuju od odraslih samo uporabom zamjeničke, ali se obje skupine djece razlikuju od odraslih i uporabom nulte anafore. Djeca predškolske dobi najviše odstupaju od točnog označavanja likova u svojim pričama. Ovo ispitivanje upućuje na dobne jezične osobitosti i razvojne promjene u označavanju likova.
\end{abstract}

\begin{abstract}
In both domains of speech-language pathology - research and professional practice - the narrative is considered a fairly natural and straightforward tool for language assessment, by means of which speaker's language use can be precisely determined beyond the sentence level. Introducing and maintaining characters adequately in a story is only one of the principles that a child needs to acquire by a wellestablished discourse in order to ensure effective communication with the audience. Therefore, the aim of this research was to investigate the ability to refer to characters in stories that were elicited using the Croatian version of Multilingual Assessment Instrument for Narratives (MAIN). The research involved a group of 23 preschool-age children, a group of 23 early school-age children and 23 adult participants, who were all asked to tell a story based on the stimulus pictures. The analysis revealed that both groups of children differ from adults in the way they reintroduce characters in stories, considering three observed referring expressions - noun phrases, pronouns and null anaphors. In maintaining characters, preschool-aged children differ from adults only in pronoun usage, but both groups of children differ from adults in the number of null anaphors. Preschool-aged children deviate the most from adequate character referencing in their stories. This research points out age-related language features and developmental changes in character referencing.
\end{abstract}

Ključne riječi: pragmatičke vještine pripovijedanje - uvođenje $\mathrm{i}$ održavanje likova anafora MAIN

Keywords: pragmatic skills - narrative ability introducing and maintaining characters anaphora MAIN 


\section{UVOD}

Jezična procjena složen je i vremenski zahtjevan postupak prikupljanja podataka o govornikovim jezičnim sposobnostima. Ne čudi stoga što je jedno od temeljnih pitanja kliničara-logopeda: kako na što brži, ali učinkovit način prikupiti potrebne vjerodostojne podatke.

Brojne znanstvene i stručno-kliničke studije ističu pripovijedanje metodom iznimne ekološke valjanosti. Primjenom te metode dobiva se sveobuhvatni opis jezičnih sposobnosti govornika (Stockman, 1996). Botting (2002) navodi tri empirijski provjerena i teorijski utemeljena razloga zašto bi pripovijedanje trebalo upotrebljavati kao obaveznu mjeru jezične procjene: 1. normativni podatci na standardiziranim testovima za procjenu pripovjedne sposobnosti (primjerice, The Bus story, Renfrew, 1991) upućuju na razvojne promjene, što omogućava usporedbu različitih dobnih skupina; 2. pripovijedanje je pragmatička vještina, koja se potvrdila uspješnom u razlikovanju različitih kliničkih skupina poput razvojnog jezičnog poremećaja (RJP-a) i jezičnih poremećaja s pretežito pragmatičkim teškoćama; 3. potvrđena je visoka i značajna povezanost pripovjedne sposobnosti i vještine pismenosti.

$\mathrm{U}$ skladu s navedenim razlozima važnosti primjene pripovijedanja u kliničkom radu, svrha je ovog rada prikazati sposobnost pripovijedanja djece kasne vrtićke i rane školske dobi, ali usmjeravajući se samo na njihovu vještinu označavanja likova u priči.

\section{Označavanje likova u priči}

Jedan od aspekata razvoja jezične sposobnosti je i usvajanje pragmatičkih načela, odnosno načela upravljanja organiziranjem obavijesti u iskazima i među iskazima s ciljem stvaranja kohezivnog diskursa (Hickmann, 1995). Pravilno označavanje i održavanje likova u priči jedno je od načela kojim dijete tijekom razvoja pripovjedne sposobnosti treba ovladati, kako bi vlastitom pričom uspješno prenijelo slušatelju sve potrebne informacije.

Za postizanje referencijalne kohezije, potrebno je znanje o označavanju likova i znanje o njihovom kontinuiranom pravilnom održavanju tijekom pripovijedanja. Likove je potrebno uvesti u priču, tako da ih sugovornik može prepoznati kao nove u priči, te ih je nakon prvog spominjanja potrebno održati u priči uporabom određenih leksema ili morfoloških oblika riječi, koje će sugovorniku omogućiti prepoznavanje likova prethodno uvedenih u priču (AksuKoç i Nicolopoulou, 2014; Hickmann, 2003).

Likovi se prilikom pripovijedanja kao nova informacija uvode imenskom riječju, a dalja referiranja ovise o udaljenosti referenta (Givón, 1983). Dakle, što je udaljenost između prvog spominjanja i održavanja veća, potrebno je određeni lik ponovno uvesti u priču, to se najčešće ostvaruje imenicom. Što je udaljenost manja, slušatelj može prepoznati lik ako ga se odř̌i zamjenicom ili označi putem glagolskog oblika iz kojeg se može dobiti informacija o licu, broju i rodu imenske riječi na koju se odnosi. Time se uspostavljaju anaforički odnosi, koji su i po definiciji tip odnosa u kojem je interpretacija drugoga oblika riječi uvjetovana interpretacijom prvoga (tzv. antecedenta; Halliday i Hasan, 1976). Stoga se govori o zamjeničkoj ili glagolskoj (nultoj) anafori.
Izostankom dijeljenog konteksta, odnosno kada sugovornik nije unaprijed upoznat s pričom, odabir leksičkih elemenata kao i oblikovanje sintaktičkih struktura, kojima se prenose informacije iz priče, pripovjedač određuje na osnovi sugovornikovog prethodnog znanja. Referiranje se može smatrati odgovarajućim ako je u skladu sa sugovornikovim znanjem, dijeljenim fizičkim i lingvističkim kontekstom (Schneider i Hayward, 2010). Naime, prilikom pripovijedanja potrebno je nadgledati razumljivost sadržaja, riječi i oblike kojima se postiže referencijalna kohezija te pratiti sugovornikove reakcije i sadržaj kontinuirano prilagođavati njegovu znanju i iskustvu (Botting, 2002). Primjerice, zamjenička anafora signalizira da je slušatelj upoznat s kontekstom priče - ili dijeljenim fizičkim ili lingvističkim kontekstom (Fossard i sur., 2018; Kaderavek i Sulzby, 2000).

Osim na vještinu označavanja likova, interes istraživača bio je usmjeren i na odstupanja u pravilnom referiranju koja dovode do narušavanja referencijalne kohezije (Liles, Duffy, Merrit i Purcel, 1995; Schneider i Hayward, 2010). Pritom su se promatrala nepotpuna označavanja likova - koja se odnose na referiranje likova koji prethodno nisu bili uvedeni u priču, ili nepravilna referiranja - koja dovode do toga da sugovornik ne može jasno prepoznati antecedenta putem anaforičkog odnosa. Nalazi upućuju na zaključak da su (ne)pravilna referiranja u funkciji dobi, odnosno uspješnim se označavanjem i održavanjem likova u priči ovladava porastom prema starijoj školskoj dobi.

Jedini opis razvojnih promjena u referiranju likova $u$ hrvatskom jeziku dala je Trtanj (2015), koja je u svome istraživanju promatrala kojim oblicima riječi djeca uvode likove i koliko su uspješni u održavanju referencije na njih, odnosno kojim ih oblicima riječi drugi puta spominju prilikom pripovijedanja. Osim toga, autorica je analizirala označavanje likova s obzirom na rečeničnu strukturu, tj. poredak riječi u rečenici. Sve četiri dobne skupine četverogodišnjaci, šestogodišnjaci, osmogodišnjaci i desetogodišnjaci ispitani u tom radu - učestalo rabe imensku i nultu anaforu, a potom zamjeničku za održavanje likova u priči. Pritom se najmlađi ispitanici u sljedećim spominjanjima referiraju na likove češće bez jasnog antecedenta ili navode imenske skupine, nižući rečenice bez međurečeničnog i anaforičkog povezivanja. Iz navedenog autorica zaključuje da im njihove jezične mogućnosti organiziranja priče često ograničavaju ostvarivanje svih pripovjedačkih potreba. S druge strane, šestogodišnjaci pripovijedaju sadržajnije, a njihove su priče naprednije jer počinju upotrebljavati i zamjenice anaforički. Postizanje referencijalne kohezije obilježje je dobnih skupina osmogodišnjaka i desetogodišnjaka. Tek najstarija skupina djece sustavno vodi likove kroz priču, upotrebljavajući zamjeničku i nultu anaforu koje su u suodnosu s imenskom anaforom. $\mathrm{Na}$ tom suodnosu počiva uspješno prepoznavanje likova, time i razumljivost sadržaja priče. Upravo nedostatak podataka o načinima označavanja likova u oblikovanju priče u hrvatskom jeziku bio je glavna motivacija za provođenje ispitivanja s ciljevima usmjerenim tim vještinama u pripovijedanju.

\section{CILJ I PRETPOSTAVKE ISTRAŽIVANJA}

Cilj je ovog rada ispitati vještine ponovnog uvođenja i 
održavanja likova tijekom pripovijedanja djece predškolske i rane školske dobi i usporediti ih s vještinama odraslih osoba. Rad se temelji na trima pretpostavkama:

1. Djeca predškolske i rane školske dobi na drukčiji će način, u odnosu na odrasle osobe, ponovno uvoditi likove u priču. Očekuje se da će djeca češće upotrebljavati zamjeničku i nultu anaforu za ponovno uvođenje likova od odraslih, a odrasli češće - imensku.

2. Djeca predškolske i rane školske dobi jednako će kao i odrasli upotrebljavati imenske skupine za održavanje likova u priči. Za funkciju održavanja likova u diskursu, razlike između svih ispitanih skupina očekuju se u broju proizvedenih nultih anafora, no ne i u broju zamjenica.

3. Očekuje se da će pravilno označavanje likova prevladavati nad odstupanjima u označavanju likova kod svih dobnih skupina. Također, očekuje se da će djeca mlađe dobi više griješiti u referiranju i održavanju likova u odnosu na djecu starije dobi i odrasle.

\section{METODE}

\section{Ispitanici}

$\mathrm{U}$ istraživanju su sudjelovale tri skupine ispitanika. Skupina djece razdijeljena je prema dobi na mlađu i stariju skupinu. Mlađoj dobnoj skupini pripada 23 djece predškolske dobi polaznika dječjeg vrtića (5;04 - 6;05 godina; $\mathrm{M}=72,22$ i $\mathrm{SD}=4,317$ izraženo u mjesecima). Skupinu kronološki starije djece čini 23 djece rane školske dobi (6;06 - 7;06 godina; $\mathrm{M}=80,87$ i $\mathrm{SD}=3,293$ izraženo u mjesecima), odnosno polaznika prvog razreda. Uzorak čini i 23 odraslih osoba kontrolne skupine (24 - 76 godina; $\mathrm{M}=39,74$ i $\mathrm{SD}=15,627$ izraženo u godinama). U svakoj je skupini podjednaka zastupljenost ispitanika prema spolu, a ispitanici u kontrolnoj skupini jednako su raspoređeni $i$ prema dobi, i to uzastopce u razdobljima od po deset godina - od 20 godine do 80. Svi sudionici ispitivanja, i djeca i odrasli, urednog su jezičnog razvoja i kognitivnih sposobnosti.

\section{Istraživački materijal}

Kao istraživački materijal upotrijebljen je slikovni predložak iz Multilingual Assessment Instrument for Narratives (MAIN; Gagarina i sur., 2012, 2015), odnosno iz njegove hrvatske inačice (Vǐ̌ejezični instrument za ispitivanje pripovijedanja, Hržica i Kuvač Kraljević, 2012). U ovom istraživanju za poticanje pripovijedanja odabrane su dvije priče, Koze i Ptice, koje se sastoje od šest povezanih slika. Priče služe za procjenu sposobnosti samostalnog oblikovanja priče, i to kod jednojezičnih i dvojezičnih govornika u dobi od 3 do 10 godina. S obzirom na to da su obje priče ujednačene po svim segmentima (broju epizoda, broju i vrsti ciljanih izraza za označavanje unutarnjih stanja, čestotnosti riječi i sl.), istodobna primjena obiju priča i zajednička analiza prikupljenih podataka na objema je opravdana. Primjenom ovog materijala u analizi se može usmjeriti na makrostrukturalnu razinu (Kuvač Kraljević i sur., u tisku), ili mikrostrukturalnu razinu, čije su mjere dijelom određene protokolom za analizu (primjerice, analiza semantičkih funkcija glagola), ili se mjere mogu jednostavno upotrijebiti na osnovi njihove ovjerenosti u drugim istraživanjima. Materijal je razvila višejezična radna skupina Narrative and Discourse u sklopu projekta Language Impairment in a Multilingual Society (BI-SLI, COST ISO804; www.bisli.org) koji se provodio od 2010. do 2013. godine. Isti je preveden u 30 tipološki različitih jezika koji se govore u različitim kulturnim kontekstima, tijekom izrade oblikovan je i dorađen u više navrata u pilot-istraživanjima koja su se provodila u većem broju jezika na više od 550 sudionika (Gagarina i sur., 2012, 2015). Instrument može biti primijenjen u istraživačke i kliničke svrhe.

\section{Postupak istraživanja $i$ analiza podataka}

Svako dijete ispitano je pojedinačno u svom vrtiću ili školi, tako da je simuliran uvjet nedijeljenog konteksta. To znači da je ispitivač svakom djetetu ponudio četiri kruga različitih boja, čija je svrha bila stvoriti sudioniku prividnu mogućnost biranja priče. Koji god krug bi sudionik odabrao, otvarala se uvijek ista priča - ili priča Koze ili priča Ptice. Na opisani se način uvjerilo dijete da ispitivač ne zna koju priču dijete priča te se tako unaprijed osigurala veća proizvodnja. Dijete je imalo vremena osmisliti i na osnovi povezanih slika oblikovati vlastitu priču, a da pritom ispitivač nije gledao što slikovni predložak prikazuje. Isti je postupak proveden i s odraslim osobama. U mlađoj skupini 12 je ispitanika ispričalo priču Koze, a 11 priču Ptice, u starijoj skupini djece 14 ih je ispričalo priču Koze, a 9 priču Ptice. U kontrolnoj skupini 14 je odraslih ispitanika ispričalo priču Koze, a 9 priču Ptice. Sve su priče zvučno snimljene, transkribirane u programu CLAN, vodeći se semantičkim kriterijem razdvajanja iskaza na C-jedinice. Svaka C-jedinica prilikom transkribiranja predstavlja najmanji dopušteni iskaz koji u komunikacijskoj situaciji može stajati samostalno, a to je gramatički gledano najčešće glavna surečenica, nezavisno složena surečenica ili glavna surečenica zajedno sa svojim subordiniranim (zavisnim) surečenicama (Loban, 1966). Transkripti su obrađeni u programu za računalnu obradu CHAT (MacWhinney, 1997). Dobiveni podaci statistički su analizirani u programskom paketu IBM SPSS 22.0.

$\mathrm{U}$ analizi dobivenih prijepisa bilježilo se kako djeca označavaju pet likova u priči Kože: mamu kozu, dva kozlića, lisicu i pticu, te pet likova u priči Ptice: mamu pticu, dvije ptičice, mačku i psa. Označavanje likova promatrano je putem dviju funkcija u diskursu (Aksu-Koç i Nicolopoulou, 2014; Fossard i sur., 2018):

1. ponovno uvođenje likova u prič - odnosi se na referiranje likova koji su prethodno uvedeni u priču, no fokus pripovjedačeva interesa između njihovog prvog $\mathrm{i}$ ponovnog uvođenja mijenjao se i prebacivao na druge likove ili događaje;

2. održavanje likova u priči - pripovjedač se kontinuirano nastavlja referirati na prethodno spomenuti lik te se fokus interesa nije prebacivao na druge likove $\mathrm{i}$ time nije bio prekinut drugim događajima.

3. Promatralo se koji se oblici i vrste riječi upotrebljavaju kao načini označavanja likova. U skladu s obilježjima hrvatskoga jezika u imenske anafore uključene su imenice (npr. koza, lisica, ptica), imenske sintagme (npr. mama koza, mala ptičica), poimeničeni pridjevi (npr. velika) i brojevne imenice (npr. drugi) u službi subjekta ili objekta u 
rečenicama. U zamjeničku anaforu ubrojene su sve vrste zamjenica (osobne, pokazne i druge). Treće, bilježile su se $\mathrm{i}$ nulte anafore (npr. kad se Ø počela približavati kozlićn,...). Anafore kojima su se likovi označavali skupno ili u množini nisu se uključile u analizu (npr. obitelj koza, dvije ptičice, oni).

Pri analizi odstupanja u označavanju likova, kao zavisne varijable određena su pravilna i nepravilna ponovna uvodenja zamjeničkom $i$ nultom anaforom.

Nadalje, kao zavisna varijabla promatrana su nepravilna označavanja likova u diskursu. $\mathrm{Na}$ operacionalnoj razini ona su analizirana tako da je ukupan broj nepravilnih označavanja u diskursu izražen zbrojem neodređenih imenskih riječi u označavanju likova koza i ptica, te svih nejasnih referiranja. Broj neodređenih imenskih riječi mjeren je ukupnim brojem imenica u označavanju istovjetnih likova koza i ptica, na osnovi kojih se ne može točno prepoznati koji je lik označen. Broj nejasnih referiranja predstavlja ukupni broj zamjenica i nultih anafora iz kojih se ne može prepoznati imenska riječ (antecedent) na koju se odnosi, kao i pogreške u uporabi zamjenica ili glagola koje slušatelja dovode do pogrešnog tumačenja o liku. Sva gramatička odstupanja (npr. leksičke zamjene, morfološke pogreške) koja ne utječu na razumljivost sadržaja priče i prepoznavanje likova - nisu uključena u analizu.

Na osnovi prethodnog opisa proizlaze sljedeće varijable:

1. Ponovno uvođenje likova imenskom anaforom.

2. Ponovno uvođenje likova zamjeničkom anaforom.

3. Ponovno uvođenje likova nultom anaforom.

4. Održavanje likova imenskom anaforom.

5. Održavanje likova zamjeničkom anaforom.

6. Održavanje likova nultom anaforom.

7. Pravilno ponovno uvođenje likova zamjeničkom i nultom anaforom.

8. Nepravilno ponovno uvođenje likova zamjeničkom i nultom anaforom.

9. Nepravilno označavanje likova u diskursu.

\section{REZULTATI I RASPRAVA}

Za dobivanje osnovne spoznaje o načinima označavanja likova nakon prvog uvođenja u pripovijedanju te istraživanja brojnosti pogrešaka u referiranju, ukupna su postignuća uspoređena na svim varijablama između dviju skupina djece i odraslih osoba.

Normalnost distribucije rezultata provjerena je Kolmogorov-Smirovljevim testom, koji je pokazao da distribucija rezultata statistički značajno odstupa od normalne na svim ispitanim varijablama $(p<0,01)$, zbog čega se u daljoj obradi podataka pristupilo neparametrijskim testovima. Kako bi se utvrdilo postoje li razlike među ispitanim skupinama, proveden je Mann-Whitneyev U-test, a za unutargrupna postignuća na određenim varijablama primijenjen je Wilcoxonov test ekvivalentnih parova.

Deskriptivni podatci za sve varijable sadržani su u tablicama u sljedećim poglavljima s izračunatim osnovnim elementima deskriptivne statistike: središnjom vrijednosti (C), pripadajućim poluinterkvartilnim raspršenjem (Q) te rasponom između najvećeg (Max) i najmanjeg (Min) rezultata.
Analiza varijabli ponovno uvođenje likova imenskom, zamjeničkom i nultom anaforom

U prvom dijelu istraživanja namjera je bila provjeriti: razlikuju li se mlađa $i$ starija skupina djece te odrasli u uporabi različitih vrsta riječi za ostvarivanje funkcije ponovnog uvođenja likova u priču.

Tablica 1. Podaci deskriptivne analize za varijable ponovnog uvođenja likova

\begin{tabular}{|l|l|c|c|c|c|c|}
\hline Varijable & Ispitanici & N & C & Q & Min & Max \\
\hline $\begin{array}{l}\text { Ponovno } \\
\text { uvođenje } \\
\text { likova }\end{array}$ & Mlađi & 23 & 5 & 3 & 1 & 16 \\
\cline { 2 - 7 } $\begin{array}{l}\text { imenskom } \\
\text { anaforom }\end{array}$ & Stariji & 23 & 4 & 1,5 & 0 & 21 \\
\cline { 2 - 7 } & Odrasli & 23 & 9 & 5 & 1 & 26 \\
\hline $\begin{array}{l}\text { Ponovno } \\
\text { uvođenje } \\
\text { likova } \\
\text { zamjeničkom } \\
\text { anaforom }\end{array}$ & Mlađi & 23 & 0 & 0,5 & 0 & 5 \\
\cline { 2 - 7 } & Stariji & 23 & 0 & 0 & 0 & 1 \\
\hline $\begin{array}{l}\text { Ponovno } \\
\text { uvođenje } \\
\text { likova } \\
\text { nultom } \\
\text { anaforom }\end{array}$ & Mlađi & 23 & 0 & 0 & 0 & 2 \\
\cline { 2 - 7 } & Stariji & 23 & 0 & 0 & 0 & 3 \\
\cline { 2 - 7 } & Odrasli & 23 & 0 & 0 & 0 & 0 \\
\hline
\end{tabular}

Legenda: $\mathrm{N}=$ broj ispitanika; $\mathrm{C}=$ središnja vrijednosti; $\mathrm{Q}=$ poluinterkvartilno raspršenje središnje vrijednosti; Min=najmanji rezultat; Max=najveći rezultat

Analizom tablice 1 razvidno je da sve skupine ispitanika najčešće likove uvode imenskom anaforom. Nadalje, veći broj zamjenica i glagola za ponovno uvođenje likova u priču upotrebljava mlađa, potom starija skupina djece, a najmanje odrasle osobe. Središnje vrijednosti pokazuju da odrasli, osim što u značajnijoj mjeri upotrebljavaju imenice, više puta označavaju likove i ponovno ih uvode u priču.

Tablica 2. Rezultati Mann-Whitneyevog U-testa za varijablu Ponovno uvodenje likova imenskom anaforom

\begin{tabular}{|l|c|c|c|}
\hline Skupine & $\mathbf{U}$ & $\mathbf{z}$ & $\mathbf{p}$ \\
\hline $\begin{array}{l}\text { Mlađi- } \\
\text { Stariji }\end{array}$ & 230,000 & $-0,765$ & 0,444 \\
\hline $\begin{array}{l}\text { Mlađi- } \\
\text { Odrasli }\end{array}$ & 165,500 & $-2,181$ & $0,029 *$ \\
\hline $\begin{array}{l}\text { Stariji- } \\
\text { Odrasli }\end{array}$ & 138,000 & $-2,791$ & $0,005^{* *}$ \\
\hline
\end{tabular}

Legenda: $\mathrm{U}=\mathrm{U}$ vrijednost Mann-Whitneyevog testa; $\mathrm{z}=$ standardizirana $\mathrm{U}$ vrijednost; $\mathrm{p}=$ značajnost na razini od $\mathrm{p}<0,05(*)$ i $\mathrm{p}<0,01(* *)$

U skladu s očekivanjima, statističkom je analizom utvrđeno da postoje značajne razlike u ponovnom uvođenju likova imenskom anaforom između obje skupine djece i odraslih ispitanika (tablica 2), kao i u ponovnom uvođenju likova nultom anaforom (tablica 4). Razlika u uporabi zamjenica u ponovnom uvođenju prisutna je samo između mlađe skupine djece i odraslih (tablica 3). Time je 
potvrđeno da djeca predškolske i rane školske dobi na drukčiji način, u odnosu na odrasle, ponovno uvode likove u priču. Odrasle osobe u značajno većoj mjeri upotrebljavaju imenice, u usporedbi s djecom, a u analizi zamjenica i glagolskih oblika rezultati pokazuju da ih djeca češće upotrebljavaju od odraslih.

Iz dobivenih se podataka može zaključiti da mjere na funkciji ponovnog uvođenja likova mogu razlikovati djecu predškolske i rane školske dobi od kontrolne skupine.

Tablica 3. Rezultati Mann-Whitneyevog U-testa za varijablu Ponovno uvođenje likova zamjeničkom anaforom

\begin{tabular}{|l|c|c|c|}
\hline Skupine & $\mathbf{U}$ & $\mathbf{z}$ & $\mathbf{p}$ \\
\hline $\begin{array}{l}\text { Mlađi- } \\
\text { Stariji }\end{array}$ & 220,000 & $-1,238$ & 0,216 \\
\hline $\begin{array}{l}\text { Mlađi- } \\
\text { Odrasli }\end{array}$ & 184,000 & $-2,555$ & $0,011^{*}$ \\
\hline $\begin{array}{l}\text { Stariji- } \\
\text { Odrasli }\end{array}$ & 221,000 & $-1,636$ & 0,102 \\
\hline
\end{tabular}

Legenda: $\mathrm{U}=\mathrm{U}$ vrijednost Mann-Whitneyevog testa; $\mathrm{z}=$ standardizirana $\mathrm{U}$ vrijednost; $\mathrm{p}=$ značajnost na razini od $\mathrm{p}<0,05\left(^{*}\right)$

Tablica 4. Rezultati Mann-Whitneyevog U-testa za varijablu Ponovno uvodenje likova nultom anaforom

\begin{tabular}{|l|c|c|c|}
\hline Skupine & $\mathbf{U}$ & $\mathbf{z}$ & $\mathbf{p}$ \\
\hline $\begin{array}{l}\text { mlađi- } \\
\text { stariji }\end{array}$ & 218,500 & $-1,317$ & 0,188 \\
\hline $\begin{array}{l}\text { mlađi- } \\
\text { odrasli }\end{array}$ & 172,500 & $-3,067$ & $0,002^{* *}$ \\
\hline $\begin{array}{l}\text { stariji- } \\
\text { odrasli }\end{array}$ & 218,500 & $-2,069$ & $0,039 *$ \\
\hline
\end{tabular}

Legenda: $\mathrm{U}=\mathrm{U}$ vrijednost Mann-Whitneyevog testa; $\mathrm{z}=$ standardizirana $\mathrm{U}$ vrijednost; $\mathrm{p}=$ značajnost na razini od $\mathrm{p}<0,05(*)$ i $\mathrm{p}<0,01(* *)$

Analiza varijabli održavanje likova imenskom, zamjeničkom i nultom anaforom

Željelo se istražiti koju anaforu s obzirom na vrstu riječi upotrebljavaju ispitanici za referiranje na prethodno spomenute likove. Drugim riječima, bilježilo se kojim se vrstama riječi ispitanici referiraju na isti lik u nizu i tako ga održavaju u priči.

Iz tablice 5 vidljivo je da odrasli najčešće održavaju likove u priči putem nulte anafore, dok su obje skupine djece gotovo ujednačene u načinima održavanja likova.

Statistička analiza na varijabli održavanja likova imenskom anaforom, pokazuje da ne postoje značajne razlike u uporabi ovih vrsta anafora između tri skupine ispitanika (tablica 6).

Statističkom je analizom utvrđeno da statistički značajne razlike u upotrebi zamjeničke anafore postoje između mlađe djece i odraslih ispitanika, dok razlike između starije skupine djece i odraslih te između dviju skupina djece nisu dosegnule statističku značajnost. To bi značilo da djeca uspostavljaju anaforičke odnose zamjenicom, no samo se mlađa skupina djece u tome značajno razlikuje od odraslih (tablica 7).
Tablica 5. Podaci deskriptivne analize za varijable održavanja likova u priči

\begin{tabular}{|l|l|c|c|c|c|c|}
\hline Varijable & Ispitanici & N & C & Q & Min & Max \\
\hline \multirow{2}{*}{$\begin{array}{l}\text { Održavanje } \\
\text { likova }\end{array}$} & Mladi & 23 & 2 & 1,5 & 0 & 5 \\
\cline { 2 - 7 } $\begin{array}{l}\text { imenskom } \\
\text { anaforom }\end{array}$ & Stariji & 23 & 2 & 0,5 & 0 & 4 \\
\cline { 2 - 7 } & Odrasli & 23 & 3 & 1,5 & 0 & 7 \\
\hline $\begin{array}{l}\text { Održavanje } \\
\text { likova } \\
\text { zamjeničkom } \\
\text { anaforom }\end{array}$ & Mladi & 23 & 2 & 1,5 & 0 & 7 \\
\cline { 2 - 7 } & Stariji & 23 & 2 & 1 & 0 & 8 \\
\cline { 2 - 7 } $\begin{array}{l}\text { Održavanje } \\
\text { likova nultom } \\
\text { anaforom }\end{array}$ & Odrasli & 23 & 3 & 2 & 0 & 7 \\
\cline { 2 - 7 } & Mladi & 23 & 2 & 1,5 & 0 & 21 \\
\cline { 2 - 7 } & Odrasii & 23 & 4 & 1 & 1 & 7 \\
\hline
\end{tabular}

Legenda: $\mathrm{N}=$ broj ispitanika; $\mathrm{C}=$ središnja vrijednosti; $\mathrm{Q}=$ poluinterkvartilno raspršenje središnje vrijednosti; Min=najmanji rezultat; Max=najveći rezultat

Tablica 6. Rezultati Mann-Whitneyevog U-testa za varijablu Odř̌avanje likova imenskom anaforom

\begin{tabular}{|l|c|c|c|}
\hline Skupine & $\mathbf{U}$ & $\mathbf{z}$ & $\mathbf{p}$ \\
\hline $\begin{array}{l}\text { Mlađi- } \\
\text { Stariji }\end{array}$ & 243,500 & $-0,473$ & 0,636 \\
\hline $\begin{array}{l}\text { Mlađi- } \\
\text { Odrasli }\end{array}$ & 209,500 & $-1,233$ & 0,217 \\
\hline $\begin{array}{l}\text { Stariji- } \\
\text { Odrasli }\end{array}$ & 188,500 & $-1,702$ & 0,089 \\
\hline
\end{tabular}

Legenda: $\mathrm{U}=\mathrm{U}$ vrijednost Mann-Whitneyevog testa; $\mathrm{z}=$ standardizirana $\mathrm{U}$ vrijednost; $\mathrm{p}=$ značajnost na razini od $\mathrm{p}<0,05$

Tablica 7. Rezultati Mann-Whitneyevog U-testa za varijablu Odř̌avanje likova zamjeničkom anaforom

\begin{tabular}{|l|c|c|c|}
\hline Skupine & $\mathbf{U}$ & $\mathbf{z}$ & $\mathbf{p}$ \\
\hline $\begin{array}{l}\text { Mlađi- } \\
\text { Stariji }\end{array}$ & 220,000 & $-1,001$ & 0,317 \\
\hline $\begin{array}{l}\text { Mlađi- } \\
\text { Odrasli }\end{array}$ & 165,500 & $-2,217$ & $0,027^{*}$ \\
\hline $\begin{array}{l}\text { Stariji- } \\
\text { Odrasli }\end{array}$ & 193,500 & $-1,592$ & 0,111 \\
\hline
\end{tabular}

Legenda: $\mathrm{U}=\mathrm{U}$ vrijednost Mann-Whitneyevog testa; $\mathrm{z}=$ standardizirana $\mathrm{U}$ vrijednost; $\mathrm{p}=$ značajnost na razini od $\mathrm{p}<0,05\left(^{*}\right)$

Tablica 8. Rezultati Mann-Whitneyevog U-testa za varijablu Održavanje likova nultom anaforom

\begin{tabular}{|l|c|c|c|}
\hline Skupine & $\mathbf{U}$ & $\mathbf{z}$ & $\mathbf{p}$ \\
\hline $\begin{array}{l}\text { Mlađi- } \\
\text { Stariji }\end{array}$ & 195,500 & $-1,538$ & 0,124 \\
\hline $\begin{array}{l}\text { Mlađi- } \\
\text { Odrasli }\end{array}$ & 54,500 & $-4,637$ & $0,000^{* *}$ \\
\hline $\begin{array}{l}\text { Stariji- } \\
\text { Odrasli }\end{array}$ & 53,500 & $-4,664$ & $0,000^{* *}$ \\
\hline
\end{tabular}

Legenda: $\mathrm{U}=\mathrm{U}$ vrijednost Mann-Whitneyevog testa; $\mathrm{z}=$ standardizirana $\mathrm{U}$ vrijednost; $\mathrm{p}=$ značajnost na razini od $\mathrm{p}<0,01(* *)$ 
Nešto drukčiji rezultati dobiveni su između djece i odraslih u održavanju likova nultom anaforom. Statistički značajna razlika ponovno nije pronađena između dvije skupine djece. No, razlika postoji između odraslih i obje skupine djece, što upućuje na to da broj upotrijebljenih glagolskih oblika raste prema starijim dobnim skupinama. To potencijalno upućuje na razvojnu dimenziju u referiranju na likove nultim anaforama (tablica 8).

\section{Analiza odstupanja u označavanju likova}

Osim ispitivanja sposobnosti održavanja i ponovnog uvođenja likova u priču cilj je rada ispitati i odstupanja u označavanju likova.

Tablica 9. Podaci deskriptivne analize za varijable Pravilno i Nepravilno ponovno uvodenje likova zamjenickom i nultom anaforom

\begin{tabular}{|l|l|c|c|c|c|c|}
\hline Skupina & $\begin{array}{l}\text { Usporedba } \\
\text { postignuća }\end{array}$ & N & C & Q & Min & Max \\
\hline \multirow{2}{*}{ Mlađi } & Pravilno & 23 & 5 & 3 & 1 & 16 \\
\cline { 2 - 7 } & Nepravilno & 23 & 0 & 0,5 & 0 & 8 \\
\hline \multirow{2}{*}{ Stariji } & Pravilno & 23 & 4 & 2 & 0 & 22 \\
\cline { 2 - 7 } & Nepravilno & 23 & 0 & 0,5 & 0 & 3 \\
\hline \multirow{2}{*}{ Odrasli } & Pravilno & 23 & 9 & 5 & 1 & 26 \\
\cline { 2 - 7 } & Nepravilno & 23 & 0 & 0 & 0 & 0 \\
\hline
\end{tabular}

Legenda: $\mathrm{N}=$ broj ispitanika; $\mathrm{C}=$ središnja vrijednosti; $\mathrm{Q}=$ poluinterkvartilno raspršenje središnje vrijednosti; $\operatorname{Min}=$ najmanji rezultat; $M a x=$ najveći rezultat

Tablica 10. Rezultati Wilcoxonovog testa ekvivalentnih parova za varijable pravilno i nepravilno ponovno uvodenje likeva zamjenickom $i$ nultom anaforom

\begin{tabular}{|l|c|c|c|}
\hline Skupine & Zbroj rangova & $\mathbf{z}$ & $\mathbf{p}$ \\
\hline \multirow{2}{*}{ Mlađi } & 253,00 & \multirow{2}{*}{$-4,112$} & $0,000^{* *}$ \\
\cline { 2 - 2 } & 0,00 & & \multirow{2}{*}{$-3,960$} \\
\hline \multirow{2}{*}{ Stariji } & 229,00 & $0,000^{* *}$ \\
\cline { 2 - 2 } & 2,00 & \multirow{2}{*}{$-4,199$} & $0,000^{* *}$ \\
\hline \multirow{2}{*}{ Odrasli } & 276,00 & \multicolumn{2}{|c|}{} \\
\cline { 2 - 3 } & 0,00 & \\
\hline
\end{tabular}

Legenda: $\mathrm{z}=$ standardizirana $\mathrm{U}$ vrijednost; $\mathrm{p}=$ značajnost na razini od $\mathrm{p}<0,01$ $(* *)$

Iz vrijednosti interkvartilnog raspršenja rezultata i raspona rezultata (tablica 9) vidljivo je da najveći broj pravilnog i najmanji broj nepravilnog označavanja imaju odrasli. Suprotno tome, najmanji broj pravilnog i najveći broj nepravilnog označavanja ima mlađa skupina djece.

Radi usporedbe postignuća u pravilnom, odnosno nepravilnom ponovnom uvođenju zamjenicom i glagolskim oblikom unutar svake skupine djece, u daljoj je obradi podataka primijenjen Wilcoxonov test ekvivalentnih parova (tablica 10). Naime, radi valjane interpretacije dobivenih rezultata na varijabli ponovnog uvođenja likova zamjeničkom i nultom anaforom, potrebno je odvojiti ona ponovna uvođenja likova u priču koja su točna i iznesena tako da sugovornik razumije koji je lik spomenut od nepravilnih uvođenja likova, zbog kojih dolazi do teškoća praćenja koji je od likova označen, time i do narušavanja referencijalne kohezije u pripovijedanju.

Uvidom u tablicu 10 vidljivo je da postoje statistički značajne razlike između pravilnih $\mathrm{i}$ nepravilnih ponovnih uvođenja likova u priču zamjeničkom i nultom anaforom kod mlađe i starije djece u korist pravilnih uvođenja. Iz navedenog se može zaključiti da prilikom ponovnog uvođenja likova djeca znaju pravilno upotrijebiti zamjenicu i glagol.

Tablica 11. Podaci deskriptivne analize za varijablu Nepravilno označavanje likova u diskursu

\begin{tabular}{|l|l|c|c|c|c|c|}
\hline Varijabla & Ispitanici & N & C & Q & Min & Max \\
\hline $\begin{array}{l}\text { Nepravilno } \\
\text { označavanje }\end{array}$ & Mlađi & 23 & 2 & 1,5 & 0 & 14 \\
\cline { 2 - 7 } $\begin{array}{l}\text { likova u } \\
\text { diskursu }\end{array}$ & Stariji & 23 & 1 & 1 & 0 & 4 \\
\cline { 2 - 7 } & Odrasli & 23 & 0 & 0 & 0 & 2 \\
\hline
\end{tabular}

Legenda: $\mathrm{N}=$ broj ispitanika; $\mathrm{C}=$ središnja vrijednosti; $\mathrm{Q}=$ poluinterkvartilno raspršenje središnje vrijednosti; $\mathrm{Min}=$ najmanji rezultat; $\mathrm{Max}=$ najveći rezultat

Iz vrijednosti interkvartilnog raspršenja rezultata i raspona rezultata (tablica 11) uočava se opadanje broja nepravilnog označavanja likova prema starijim dobnim skupinama.

Tablica 12. Rezultati Mann-Whitneyevog U-testa za varijablu nepravilno oznaćavanje likova u diskursu

\begin{tabular}{|l|c|c|c|}
\hline Skupine & $\mathbf{U}$ & $\mathbf{z}$ & $\mathbf{p}$ \\
\hline $\begin{array}{l}\text { Mlađi- } \\
\text { Stariji }\end{array}$ & 176,000 & $-2,018$ & $0,044^{*}$ \\
\hline $\begin{array}{l}\text { Mlađi- } \\
\text { Odrasli }\end{array}$ & 84,000 & $-4,453$ & $0,000^{* *}$ \\
\hline $\begin{array}{l}\text { Stariji- } \\
\text { Odrasli }\end{array}$ & 147,500 & $-3,166$ & $0,002^{* *}$ \\
\hline
\end{tabular}

Legenda: $\mathrm{U}=\mathrm{U}$ vrijednost Mann-Whitneyevog testa; $\mathrm{z}=$ standardizirana $\mathrm{U}$ vrijednost; $\mathrm{p}=$ značajnost na razini od $\mathrm{p}<0,05\left(^{*}\right)$ i $\mathrm{p}<0,01(* *)$

U ukupnom broju nepravilnih označavanja likova koje djeca čine tijekom pripovijedanja, statistička analiza pokazuje razlike između svih triju dobnih skupina ispitanika, što potvrđuje opadanje broja nepravilnog označavanja s porastom dobi. U nastavku su prikazani i kvalitativni podaci, odnosno vrste pogrešaka koje su svrstane u nejasna i nepravilna označavanja likova.

Uvidom u grafikon 1 zaključuje se da najviše pogrešaka pripada imenovanju likova na neodređen način. U svakoj priči postoje tri jednaka lika - mama koza i dva kozlića, te mama ptica i dvije ptičice - koji su u interakciji jedni s drugima. Potrebno ih je prilikom pripovijedanja jezičnim sredstvima jasno odijeliti, kako bi sugovornik koji ne dijeli isti kontekst s pripovjedačem mogao točno prepoznati koji je 
lik imenovan. Naprimjer, promotre li se rečenice Jedan mali kozlić skoči u jezero (...), Lija skoči naglo $i$ želi maloga kozlića isto uhvatiti. čini se kao da je lija htjela uhvatiti kozlića koji je skočio u jezero, a zapravo je htjela uhvatiti drugog kozlića iz priče. Najviše pogrešaka u označavanju likova na jasan i nedvosmislen način imaju mlađa djeca, zatim starija djeca, a zanimljiv je podatak da na ovaj način u pripovijedanju griješe i odrasli ispitanici.

\section{Vrste pogrešaka}

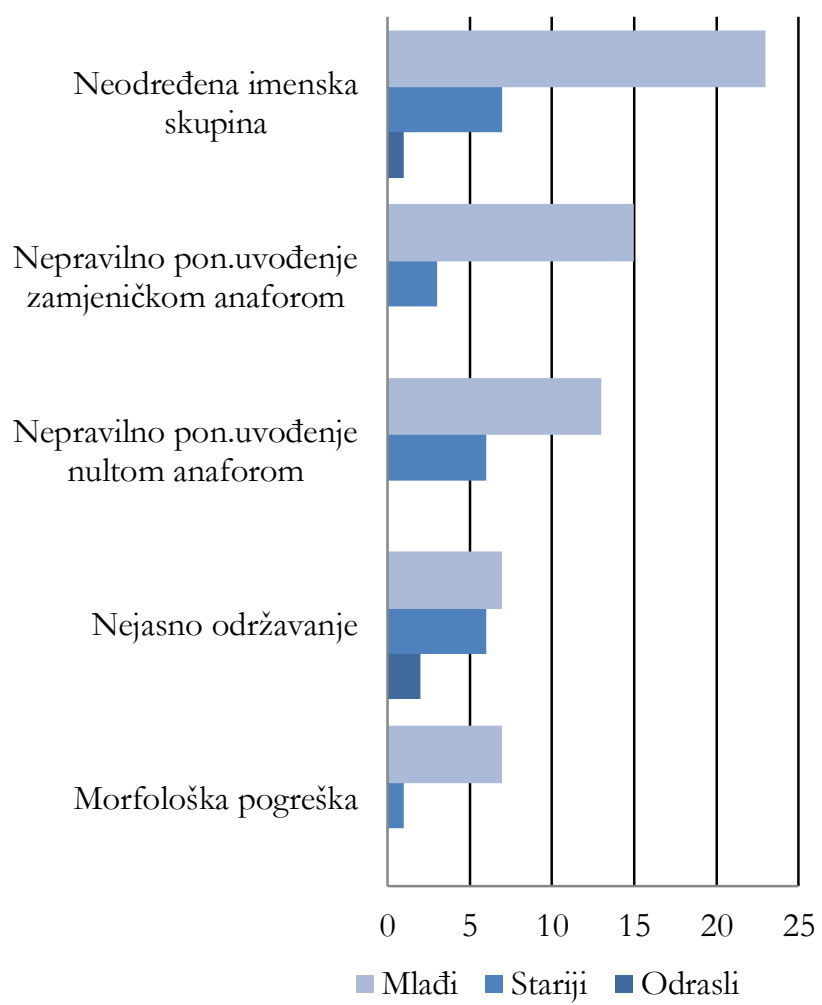

Grafikon 1. Prikaz udjela pogrešaka prema vrsti pogrešaka za svaku dobnu skupinu na varijabli Nepravilno označavanje likova u diskursu

Sljedeća vrsta pogrešaka prema učestalosti kod mlađe i starije skupine djece nepravilna su ponovna uvođenja likova zamjeničkom i nultom anaforom. Nejasno održavanje predstavlja pogreške koje čini pripovjedač kada nastavlja održavati lik u priči koji je prethodno nejasno uveden. $\mathrm{Na}$ opisani način podjednako griješe i mlađa i starija djeca, a najmanje odrasle osobe. Kod obje skupine djece najmanje su prisutne morfološke pogreške u uporabi roda i/ili broja imenica, koje utječu na sadržaj i prenesenu poruku o kojem se liku radi.

Pripovijedanje se kao alat u jezičnoj procjeni smatra dovoljno prirodnim i neposrednim da vjerodostojno odražava uporabu jezika na razini iznad rečenica, kao i eventualne razvojne osobitosti ili odstupanja koja nastaju kao posljedica povezivanja i održavanja gramatičkog ustrojstva i sadržajne informativnosti proizvedenog diskursa. U skladu s tim, cilj je ovog rada ispitati označavanje likova u pričama koje su poticane hrvatskom inačicom slikovnog materijala - Višejezični instrument za ispitivanje pripovijedanja (MAIN; Gagarina i sur., 2012, 2015; Hržica i Kuvač Kraljević, 2012).

Oblikovanje priče zahtjevan je kognitivno-jezični zadatak jer traži pravilno nizanje događaja, pritom pripovjedač mora koordinirati i integrirati količinu informacija s malo interakcijske podrške (Norbury, Gemmell i Paul, 2013). Poveže li se to s činjenicom da djeca priču trebaju ispripovijedati tako da sugovornik može shvatiti što se u kontekstu priče događa, riječi koje upotrebljavaju prilikom pripovijedanja mogu se promatrati sa stajališta komunikacijske funkcije koju ostvaruju. Time se može dobiti uvid u pragmatičke vještine pripovjedača.

$\mathrm{U}$ hrvatskome jeziku nedostaje podataka o tome kako djeca referiraju likove koje su prethodno uveli u priču u nastavku pripovijedanja, a još manje o tome što se može smatrati urednim, tj. razvojno prihvatljivim referiranjem. Kada dijete pripovijeda i griješi pri uporabi odgovarajućih riječi i oblika riječi, ne postoje referentne vrijednosti koje bi bile vodilje u donošenju odluke o (ne)postojanju teškoća u domeni referencijalne kohezije i usvajanju pragmatičkog načela organiziranja i povezivanja obavijesti u diskursu. Radi odgovora na istraživačka pitanja i dobivanja osnovne spoznaje o anaforama koje odabiru djeca, načini označavanja likova u ovom su radu razdijeljeni na dvije diskursne funkcije s obzirom na udaljenost između prvog i sljedećeg spominjanja za svaki od likova.

Ovaj se rad temelji na pretpostavci da će djetetu koje pripovijeda funkcija ponovnog uvođenja likova biti najzahtjevnija - jer se u njoj reflektira međuodnos kognitivne zahtjevnosti zadatka i ovladanosti jezičnim vještinama i njihove uporabe prilikom pripovijedanja. U skladu s tim, jedan od ciljeva ovoga rada je istražiti koje oblike riječi djeca češće upotrijebe za ovu funkciju i usporediti ih s načinima referiranja odraslih osoba.

Iz rezultata temeljenih na broju imenskih skupina koje su se bilježile za funkciju ponovnog uvođenja likova, a u usporedbi s brojem upotrijebljenih zamjenica i glagolskih oblika, može se vidjeti da kod djece postoji određena postupnost usvajanja znanja - na koji način jezično označiti prvotno spomenute likove. Djeca iz mlađe i starije skupine u svojoj jezičnoj proizvodnji upotrebljavaju imenske skupine $\mathrm{s}$ postupnim povećanjem u njihovom broju s dobi međutim, uporaba tih oblika nije dosljedna načinima ponovnog uvođenja likova odraslih osoba. Navedeno potvrduje podatak da su razlike u uporabi imenske anafore između mlađe djece i odraslih, te starije djece i odraslih, dosegnule značajnost. Slični nalazi i objašnjenja ovakvih rezultata pronalaze se i u drugim istraživanjima. Primjerice, Aksu-Koç i Nicolopoulou (2014), u svojem su istraživanju varirajući kognitivnom zahtjevnosti zadatka oblikovanja priče s obzirom na brojnost likova - zaključile da je ponovno uvođenje likova pod najvećim utjecajem broja glavnih likova u priči, odnosno da se povećanjem broja likova u priči podiže i jezična zahtjevnost zadatka baratanja jezičnim jedinicama i prilagođavanja iskaza znanju sugovornika. Pritom se imenski skup smatra najinformativnijim oblikom, u odnosu na zamjenice i glagole koji za ovu funkciju trebaju biti u semantički bogatom okružju koje podupire njihovo značenje da bi se jezična uporaba smatrala uspješnom.

$\mathrm{Na}$ osnovi rezultata, pretpostavka da će odrasli češće od 
djece upotrijebiti imeničke anafore za ponovno uvođenje likova u priču može se prihvatiti. Nadalje, potvrdila su se i očekivanja da će djeca češće upotrebljavati zamjeničke i glagolske anafore jer je odabir jedinica s jezične razine $i$ njihova uporaba u suodnosu s drugim čimbenicima unutar $i$ izvan samog diskursa.

Iz rezultata o načinima održavanja likova u priči, zaključak je da postoji postupnost u ovladavanju uspostavljanjem anaforičkih odnosa zamjenicama kod djece. Uporaba glagolskih oblika upućuje na to da navedeni oblici postupno počinju dobivati anaforičku funkciju radi povezivanja likova u priči uz blagi porast prema starijoj dobnoj skupini, ali ne toliko da dostižu odrasle ispitanike.

Aksu-Koç i Nicolopoulou (2014) u svome su istraživanju - usporedbom djece govornika engleskoga, turskoga i grčkoga jezika - zaključile da djeca vrlo rano u jezičnom razvoju počinju upotrebljavati zamjenice i da se takvo održavanje likova može smatrati dominantnom strategijom uspostavljanja anaforičkih odnosa od treće godine nadalje za djecu iz engleskoga govornoga područja, dok se u morfološki razvedenijim jezicima, poput turskoga $i$ grčkoga, za ovu funkciju očekuje podjednaka pojavnost zamjenica i imenskih skupina. Ovu tezu potvrđuje i Trtanj (2015) za hrvatski jezik. U tom se istraživanju pokazalo da četverogodišnjaci upotrebljavaju zamjenice i glagolske oblike za održavanje referencije, međutim tek se kod šestogodišnjaka može očekivati upotreba zamjenica u funkciji anafore, $i$ to $s$ jasnim, nedvosmislenim referiranjem na točne likove.

Održavanje likova imenskim skupinama ne utječe na logiku odvijanja pripovijedanja, niti na uspješnost $u$ slušateljevu prepoznavanju likova, ali može biti pokazatelj jezične kompetencije u organiziranju semantičkih, sintaktičkih i pragmatičkih načela diskursa. Primjerice, osim samih vrsta i oblika riječi, nositelji informacija o likovima i događajima u priči svakako su i sintaktičke strukture koje djeca oblikuju. Trtanj (2015) je u svome istraživanju uočila da se djeca do šeste godine pri održavanju referencije oslanjanju na kanonski red riječi, stavljajući imensku riječ na početak rečenice u subjektni položaj, odnosno da se rjeđe oslanjanju na varijaciju poretkom riječi u rečenicama, što je u oblikovanju sintaktičkih struktura složeniji postupak. Kada bi djeca više varirala poretkom riječi u rečenicama, tada bi češće upotrebljavala druge oblike riječi, odnosno zamjeničke i nulte anafore.

U skladu s dobivenim podacima, druga pretpostavka ovog rada može se djelomice prihvatiti. U dijelu koji se odnosi na to da djeca jednako kao i odrasli upotrebljavaju imeničke anafore za održavanje likova u priči pretpostavljena očekivanja su se potvrdila. Također, potvrdilo se da obje skupine djece u odnosu na odrasle proizvode manji broj nultih anafora. Međutim, u odnosu na broj zamjenica očekivanja nisu u skladu s pretpostavkom. Naime, nisu se očekivale razlike između ispitivanih skupina s obzirom na broj zamjenica upotrijebljenih za održavanje likova, a ta se razlika pokazala između mlađe djece i odraslih.

S obzirom na značajnost razlika u ponovnom uvođenju likova među skupinama, od posebne je važnosti bilo provjeriti kolika je učestalost u pravilnoj u odnosu na nepravilnu uporabu zamjenica i glagolskih oblika prilikom ponovnog uvođenja likova u priči. Djeca češće rabe pravilne oblike nego što griješe za ovu funkciju. Takvi rezultati upućuju na to da djeca većinom pokazuju razumijevanje da sugovornik ne dijeli znanje i zajednički kontekst s njima, odnosno uporabom svoga jezika i odgovarajućim izborom riječi pri navođenju likova uzimaju u obzir perspektivu sugovornika.

S druge strane, ukupno odstupanje od pravilnog referiranja još je uvijek značajno u predškolskoj i ranoj školskoj dobi. Stoviše, jedino su na varijabli ukupnog broja nepravilnih označavanja likova razlike između mlađe i starije djece značajne, posebice između obje skupine djece i odraslih. Rezultati istraživanja podržavaju očekivanja i postavljenu treću pretpostavku - ukupna odstupanja u označavanju likova kod djece ne prevladavaju nad pravilnim označavanjem, no mlađa skupina djece najviše griješi u referiranju.

Takvi nalazi upućuju na to da bi mjera ukupnog broja odstupanja u referiranju, koja bi počivala na većem uzorku ispitanika $\mathrm{i}$ iscrpnijim istraživanjima, mogla dati odgovore jesu li pogreške koje djeca čine odraz više individualnih ili potencijalno normativnih razlika među ispitanicima. Ovo istraživanje izvještava da se bilježi napredak u pravilnom označavanju, odnosno postoji pad u broju pogrešaka u usporedbi između mlađe i starije skupine djece.

U daljoj analizi odstupanja u označavanju likova, učinjene pogreške u referiranju grupirale su se prema vrsti i zastupljenosti prema dobi, a učinjene pogreške pobliže se mogu objasniti putem primjera koji slijede.

Primjer 1. Nepravilno ponovno uvođenje likova nultom anaforom (KD=6;08 god.)

*CHI: došla je ptica jedna.

*CHI: ptičice su joj otvorile usta.

${ }^{*} \mathrm{CHI}$ : onda je otišla.

*CHI: pa onda je došla jedna mačka.

${ }^{*} \mathrm{CHI}:$ i onda je dala crviće.

${ }^{*} \mathrm{CHI}:$ i onda je došla mački [*].

\%err: mački $=$ mačka

*CHI: i već se na pola popela.

*CHI: i onda je dala drugoj.

*CHI: i već je do jedne ptičice stigla.

Primjer 2. Nepravilno ponovno uvođenje lika zamjeničkom anaforom (KD=6;04 god.)

$*$ CHI: mama želi nahraniti.

*CHI: i onda želi + ...

*CHI: i onda je otišla po hranu.

*CHI: i mačka ih je želila [*] pojest(i).

\%err: želila=željela

*CHI: i onda im je dala ručak.

${ }^{*} \mathrm{CHI}$ : mačka se popela.

*CHI: i zdrabila [*] je pticu.

\%err: $\quad$ zdrabila $=$ zgrabila

U primjeru 1. prikazano je kako dijete iz starije dobne skupine ponovno uvodi likove u priču na nepravilan način. Budući da su mačka i ptica istog roda i broja, upotrijebljeni glagol dala neposredno nakon imenovanja mačke upućuje da je mačka ptičicama dala crviće umjesto ptice, a isto tako i sljedeći glagol dala i glagol stigla. Budući da organizacija diskursa na ovaj način zahtijeva funkciju ponovnog uvođenja lika u priču, a oblikovana sintaktička struktura i morfološko 
obilježavanje likova nalaže upotrebu imenske riječi kako bi informacije bile pravilno prenesene prilikom pripovijedanja, izdvojeno označavanje likova može se smatrati odstupajućim. Isto objašnjenje vrijedi i za prikazani primjer 2., s tim što je za ponovno uvođenje lika upotrijebljena zamjenica. god.)

Primjer 3. Nepravilno održavanje likova (KD=6;06

*CHI: vidim da je ova tu koza otišla spasiti ovu tu malu.

*CHI: i onda da su izašli iz rijeke.

*CHI: i onda je lisica tu kozu htjela pojesti.

${ }^{*} \mathrm{CHI}$ : i onda je ona zgrabila lisicu.

*CHI: i lovila ju.

*CHI: i onda je lisica pobjegla.

Analiza prijepisa u primjeru 3. pokazuje da je dijete prilikom pripovijedanja na nepravilan način u priču uvelo lik ptice i u nastavku pripovijedanja nepravilno ga održalo u priči. U uvjetima nedijeljenog konteksta ovakav način referiranja dovodi do pogrešnog tumačenja o kojem se liku radi, odnosno navodi na zaključak da je koza zgrabila $i$ lovila lisicu umjesto ptice kako je prikazano na slikovnom predlošku.

Primjer 4. Morfološka pogreška (KD=6;05 god.)

*CHI: a mama il(i) tata <su je mazila $>\left[{ }^{*}\right]$ kozicu.

\%err: su je mazila=je mazio

*CHI: i ova je tu gledala.

*CHI: a onda ju je ta ptica primila za rep.

*CHI: i onda je taj vuk pao na pod.

Budući da se zamjenica $j u$ odnosi na vuka s obzirom na sadržaj slikovnog predloška, morfološka pogreška u primjeru 4. primjer je jedne od morfoloških pogrešaka koje su se svrstavale u nepravilno referiranje jer bitno utječe na prepoznavanje likova.

Primjer 5. Uporaba neodređene imenske skupine (KD=44 god.)

*ADU: i <jedno malo> [/] <jedno malo> [//] jedan mali kozlić skoči u

jezero.

*ADU: koza to ugleda.

*ADU: i skoči za njim da ga spasi.

*ADU: iza drveta lukavo to sve gleda lukava lija.

*ADU: lija skoči naglo.

*ADU: i u [///] želi maloga kozlića isto uhvatiti.

U primjeru 5. istaknuto je kako odrasla osoba imenuje lik drugog malog kozlića. Usporedbom dobivenog prijepisa sa slikovnim predloškom, jasno se vidi da neodređeno dodjeljivanje semantičke oznake za drugog kozlića dovodi do pogrešnog interpretiranja da se u priči radi o jednom liku kozlića, a ne zapravo o dva kozlića kako prikazuje slikovni materijal.

Iako nisu navedeni svi primjeri odstupanja koji su se pojavili u svim dobnim skupinama, već i detaljnijom analizom ponuđenih primjera mogu se potvrditi ranije tvrdnje da pogreške nastaju zbog održavanja gramatičkog ustrojstva, referencijalne kohezije i sadržajne informativnosti u pričama s većim brojem likova.

\section{ZAKLJUČAK}

Pripovijedanje se smatra vrijednim izvorom jezičnih podataka prikupljenih $\mathrm{u}$ relativno kratkom vremenu $\mathrm{u}$ prirodnim uvjetima. Usvojenost pragmatičkog načela organiziranja obavijesti u diskurs, samo je jedno od aspekata pragmatičkog razvoja koje se može ispitati metodom pripovijedanja. U ovom istraživanju, ono se promatralo posredovanjem označavanja likova.

Iako je pripovijedanje lako primjenjiva alatka za ispitivače u dijelu provedbe ispitivanja, još postoji niz nepoznanica u dijelu tumačenja podataka. Budući da je u hrvatskome jeziku malo poznato kako djeca označavaju likove nakon uvođenja u priču, ovaj je rad usmjeren na promatranje označavanja likova nakon njihovog prvog spominjanja. Analizirani podaci iz dobivenih prijepisa priča daju jasan uvid u uspješnost referiranja likova kod djece s porastom dobi. Ovo istraživanje upućuje da su razvojne promjene kod djece prisutne u razdoblju prelaska iz predškolske u školsku dob, u vrijeme kada se dijete sve više susreće s diskursom u govoru i pismu, a pripovjedačke i pragmatičke vještine dinamično se razvijaju (vidjeti Nippold, 2007).

Istraživanje pokazuje da se djeca razlikuju od odraslih u načinima ponovnog uvođenja i održavanja likova s obzirom na tri vrste anafore obuhvaćene analizom - imensku, zamjeničku i nultu. Za ponovno uvođenje likova potvrdila su se očekivanja da će djeca manje upotrebljavati imenske skupine u usporedbi s odraslima. U odnosu na odrasle, zamjenice i glagoli brojniji su u dječjoj upotrebi. Navedeno upućuje na zaključak da djeca pokazuju osjetljivost na perspektivu sugovornika, međutim nisu u potpunosti usvojila pragmatička načela organiziranja priče. U održavanju likova mlađa se djeca razlikuju od odraslih u upotrebi zamjenica, a mladi i stariji i u upotrebi glagola. Time se pokazalo da djeca uspostavljaju anaforičke odnose zamjenicama, a rjeđe glagolskim oblicima. Naposljetku, mlađa skupina djece najviše odstupa od pravilnog označavanja likova s obzirom na broj i vrstu učinjenih pogrešaka.

Zaključno, podaci i nalazi u ovom radu mogu pomoći logopedima preciznije određivanje očekivanja za djecu predškolske i rane školske dobi u označavanju likova, kao važnog elementa ostvarivanja kohezije i koherencije na diskursnoj razini. Također, važno je da analiza dječjeg pripovjednog diskursa postane neizostavni korak u dijagnostičkom procesu, s ciljem opisivanja pragmatičkih vještina djece i odraslih.

\section{Zahvala}

Ovaj rad nastao je u sklopu projekta Višerazinski pristup govornom diskursu u jezičnom razvoju (UIP-2017-05-6603), koji financira Hrvatska zaklada za znanost projektom. 


\section{LITERATURA}

1) Aksu-Koç, A., Nicolopoulou, A. (2014). Character reference in young children's narratives: A crosslinguistic comparison of English, Greek, and Turkish. Lingua, http://dx.doi.org/10.1016/j. lingua.2014.04.006

2) Botting, N. (2002). Narrative as a tool for the assesment of linguistic and pragmatic impairments. Child Language Teaching and Therapy, 18, 1-21.

3) Fossard, M., Achim, A. M., Rousier-Vercruyssen, L., Gonzalez, S., Bureau, A., Champagne-Lavau, M. (2018). Referential Choices in a Collaborative Storytelling Task: Discourse Stages and Referential Complexity Matter. Frontiers in Psychology, 9:176. doi: 10.3389/fpsyg.2018.00176

4) Gagarina, N., Klop, D., Kunnari, S., Tantele, K., Välimaa, T., Balčiūnienè, I., Bohnacker, U., Walters, J. (2012). MAIN: Multilingual Assessment Instrument for Narratives. ZAS Papers in Linguistics, 56.

5) Gagarina, N., Klop, D., Kunnari, S., Tantele, K., Välimaa, T., Balčiūnienè, I., Bohnacker, U., Walters, J. (2015). Assessment of narrative abilities in bilingual children. U: S. Armon-Lotem, J. de Jong, N. Meir (ur.). Assesing Multilingual Children: Disentangling bilingualism for language impairment (str. 243-269). Bristol: Multilingual Matters.

6) Givón, T. (1983). Topic continuity in discourse: A quantitative crosslanguage study. Philadelphia, PA: John Benjamins.

7) Halliday, M. A. K., Hasan, R. (1976). Cohesion in English. London: Longman.

8) Hickmann, M. (1995). Discourse organization and the development of reference to person, space and time. U: P. Fletcher, B. McWhinney (Eds.). (ur.). Handbook of child language (str.194-218). Oxford: Basil Blackwell.

9) Hickmann, M. (2003). Children's discourse: Person, space and time across languages. Cambridge, UK: Cambridge University Press.

10) Hržica, G., Kuvač Kraljević, J. (2012). MAIN - hrvatska inačica: Višejezični instrument za ispitivanje pripovijedanja. U: N. Gagarina, D. Klop, S. Kunnari, K. Tantele, T. Välimaa, I. Balčiūnienè, U. Bohnacker, J. Walters. (ur.). MAIN: Multilingual Assessment Instrument for Narratives. ZASPiL 56.

11) Kaderavek, J. N., and Sulzby, E. (2000). Narrative production by children with and without specific language impairment: Oral narratives. Journal of Speech, Language and Hearing Research, 43, 34-49.

12) Kuvač Kraljević, J., Hržica, G., Vdović Gorup, I. (u tisku). Macrostructural analysis of narrative discourse in children with developmental language disorder. Drustvena istraživanja.

13) Liles, B. Z., Duffy, R. J., Merrit, D. D., Purcel, S. L. (1995). Measurement of narrative discourse ability in children with language disorders. Journal of Speech and Hearing Research, 38, 415-425.

14) Loban, W. (1966). Language Ability: Grades Seven, Eight, and Nine. Washington, DC: Government Printing Office.

15) MacWhinney, B. (1997). The CHILDES Project: Tools for Analysing Talk. New Jersey: Lawrence Erlbaum Associates.

16) Nippold, M.A. (2007). Later language development: School-age children, adolescents and young adults. Austin, TX: Pro-Ed.

17) Norbury, C.F., Gemmell, T., Paul, R. (2013). Pragmatics abilities in narrative production: a cross-disorder comparison. Journal of Child Language, 1-26.
18) Renfrew, C. (1991). The Bus Story: A test of continuous speech. Oxford: Published by author.

19) Schneider, P., Hayward, D. (2010). Who does what to whom: Introduction of referents in children's storytelling from pictures. Language, Speech and Hearing services in Schools, 41, 459-473.

20) Stockman, I. (1996). The Promises and Pitfalls of Language Sample Analysis as an Assessment Tool for Linguistic Minority Children. Language Speech and Hearing Services in Schools, 27, 355-366.

21) Trtanj, I. (2015). Jezično označavanje likova u dječjem pripovjednom diskursu (doktorska disertacija). Preuzeto iz baze podataka Filozofskog fakulteta Sveučilišta Josipa Jurja Strossmayera u Osijeku. 